\title{
Relationality and Revelation: Early Hindu Ecological Visions
}

\author{
Rita D. Sherma
}

check for

updates

Citation: Sherma, Rita D. 2021

Relationality and Revelation: Early Hindu Ecological Visions. Religions 12: 465. https://doi.org/10.3390/ rel12070465

Academic Editor: Christopher Key Chapple

Received: 10 April 2021

Accepted: 10 May 2021

Published: 24 June 2021

Publisher's Note: MDPI stays neutral with regard to jurisdictional claims in published maps and institutional affiliations.

Copyright: (C) 2021 by the author. Licensee MDPI, Basel, Switzerland. This article is an open access article distributed under the terms and conditions of the Creative Commons Attribution (CC BY) license (https:/ / creativecommons.org/licenses/by/ $4.0 /)$.
Shingal Center for Dharma Studies, Graduate Theological Union, Berkeley, CA 94709, USA; rsherma@gtu.edu

\begin{abstract}
This article, titled Relationality and Reverence: Hindu Ecological Visions, for the Special Issue on "Hinduism, Jainism, Yoga and Ecology", edited by Christopher K. Chapple, focuses on the relationship of early Hindu texts (Samhitas and Upanishads) to the natural world. In relation to this effort, it is first necessary to recognize the value that ecotheologians confer on the recovery of epistemologies of respect for the earth's ecosystems for recontextualizing theoethics and theopraxis for a viable future. The fabric of Hindu thought, from its inception, has contained strands which have been informed by a deep reverence for, and profound intimacy with, the natural world. Much of this perception and practice has become attenuated in the modern era. This paper will seek to draw attention to some key principles and perspectives within early Hindu textual traditions that can and should be ecotheologically re-evisioned for ecosystemic and societal sustainability within the "global" Hindu ethos.
\end{abstract}

Keywords: ecology; ecopraxis; Hinduism; ecotheology

\section{Introduction}

The wild and verdant places of the other-than-human world-mountains, forests, the sylvan banks of rivers, and wilderness as a whole-serve as the loci of revelation in the Hindu world. The banks of the Yamuna river, the forests, groves, and meadows in and around the pastoral village of Vrndāvana, are viewed as the sacred revelatory places of the terrestrial childhood and adolescence of the divine incarnation Krishna. It is through the vivid visualization of the enchanting beauty of Vrndāvana that the moments of revelation-evinced by scriptural witness-can be experienced through the refined imagination as sacred space and transcendent time in the immediacy of this present moment. The gratitude-filled hymns of the Rigveda and Sāmaveda - the two earliest of the first set of texts (samhitā-s) of the canonical Vedas (śruti)-express awareness of human interdependence with, and awe in face of, the abundance, majesty, and power of natural phenomena.

Most religious worldviews were formed centuries or millennia prior to the onset of the 21st century, before the disaster of climate change, the ongoing sixth mass species extinction, and the ubiquitous degradation of the earth's biogeophysical integrity-induced, according to scientific consensus, by human actions. Therefore, religious texts and traditions cannot be expected to address this particular nexus of challenges. Nevertheless, they hold many invaluable resources-philosophical, theological, practical, and ethical-which can serve as motivators for benevolent attitudes and actions that serve the wellbeing of humanity and the planetary community.

In relation to this effort, it is first necessary to recover the epistemologies of respect for the earth's ecosystems before recontextualizing theoethics and theopraxis for a viable future. This paper will seek to draw attention to some key principles and perspectives within early Hindu textual traditions that can and should be ecotheologically revisioned for ecosystemic and societal sustainability.

The fabric of Hindu thought, from its inception, has contained strands which have been informed by a deep reverence for, and profound intimacy with, the natural world. There are, as we shall see, numerous passages in the vast corpus of Hindu scripture that 
reflect a sense of attunement with the rhythms of nature that echo the sage's awe and wonder at the majesty and power of the elemental world, and evince a concern about human damage to, and pollution of, the earth, air, and bodies of water. There are also elements in the Hindu worldview that reflect an organic perspective and resonate with the insights of modern ecological consciousness. Hindu sacred embodied praxis often integrates the ecosphere either symbolically, via representations of archetypal elements common to indigenous cultures (earth, water, fire, air, space), or directly, through rituals and venerations that incorporate trees, rivers, sacred groves, mountains, and more.

\section{Reciprocity and Reverence: Hinduism as an "Indigenous Religion"}

\subsection{Ecopraxis and the Reciprocity of Reverence}

Hindu traditions are indigenous ecological spiritualties of place. The vast subcontinent, wherein lies the source of the conceptual headwaters of the tributaries of thought and vision that flowed into the river that came to be called the Hindu religion, inspired an interrelationship of reciprocity and renewal between human communities and the natural world. Indigenous religions are worldviews rooted in ecosystems. The great diversity of ecosystems on the subcontinent, its massive Himalayan peaks, broad life-giving rivers that flow astride wide plains and vast tropical forests, charismatic megafauna, and numerous climatic zones stirred awe, reverence, gratitude, and inspired theological visions of place within the hearts of the ancient seers who transmitted the Vedas. Environmental philosopher, Christopher K. Chapple has explained the positive valence of primacy accorded the ecosphere:

$[\mathrm{O}] \mathrm{n}$ the topic of environmental ethics, the Hindu tradition, which finds its primary authority in the Vedic literature, also offers conceptual resources that promote ecological sensitivity. In the Vedic hymns, we find an intimate relationship between persons and various personifications of the earth, water... and so forth. The Vedic rituals, many of which are still performed today, invoke elemental forces.

The earliest texts of the Hindu canon, the Vedas, record the veneration of the elemental forms and phenomena of the natural world. The people of the early Vedic era had a sense of reciprocal care in relation to the earth and the elements that produced both destruction and renewal (the winds, fire, water), which were sacralized and accorded a symbiotic status. The cosmic forces needed human recognition and sanctification as much as humans needed the munificence of the forces in return. The divinized forces of the natural world were nurtured and rejuvenated by the gratitude and veneration accorded them by the ritual of the Vedic sacrifice; they, in turn, were able to bestow blessings upon the world. This established a strong sense of interrelatedness with the natural world.

The visualization of elemental forces in terms of sacred cosmic geometry laid out in the yajña-kund (the elaborate fire-pit for the ritual of offerings into the element of fire) was the keystone worship ritual of the Vedic people. This reciprocal interrelationship was invoked through prayers and offerings, hymns, and mystical sounds (mantra). And it created a locus of empowerment which then could be channeled productively for the welfare of the community and the world. We will later see the return of this idea in the rituals of Tantra which focus on the evocation and channeling of divine energy.

\subsection{Theopraxis of the Reciprocity of Reverence}

Humans in this worldview did not see themselves as separate and disconnected from the rest of the cosmos. Humans, animals, plant life, the sun, the moon, the stars and, indeed, the entire cosmos, were seen as one continuum. Humans, as participants in the cosmic drama, had a special obligation to acknowledge the sacred forces that gave rise to life on an ongoing basis. When the forces and phenomena that sustain life and fecundity were unacknowledged, unrecognized, and offered no reciprocal communion (through prayers, reverence, or the offerings of the yajña), they were weakened, dispersed, and their ability to bless, fructify, and nurture was considered to be reduced. Because many Vedic rituals are still carried out, it is important to conceptualize this as the idea of an ecological consciousness, 
viewed as necessary for the benefit of humanity and nature through the sacred act of ritual. This is the theopraxis of the reciprocity of reverence.

The processes of ritual are, no doubt, primarily meant to protect the wellbeing of the human community. But, at the same time, they serve to:

(1) Create sacred space for the envisioning of the elemental powers in divinized form to ignite an ecological consciousness.

(2) Provide the necessary environment in which to offer recognition, veneration, and gratitude to the powers of nature through the offering of things of value (sacrifice).

(3) Evoke an inner conviction that the revivification and supplication of Earth's forces will bring forth blessings and plenitude for the community and the world, and help maintain, within human communities, an attitude of care.

(4) Offer appreciation and loving care for the earth's beauty and bounty as an essential religious obligation.

The indigeneity of the Hindu religion at its source, the Vedas, is expressed through the sacred hymns, which are still chanted today. The Vedas exalt the marvels of nature and regard the Earth (Pṛthvī), forests (for, e.g., Aranyānī Sūktam), and the rivers (Sarasvati, Ganga, Yamuna) as devīs (aspects of the Divine Feminine). The perception of the Earth as Mother and as a manifestation of the Divine Feminine is first seen in the Prthvī Sūktam of the Atharvaveda, where the Earth is eulogized as the lavish bestower of all precious things. But she is also the Mother who deserves our respect and protection. The perception of Earth as the mother that creates all life from her own being (and, therefore, identified as a Devi, goddess) is highly significant for a constructive ecotheology in the Hindu context. Various passages from the Prithvī Sūktam refer to such an awareness, including the following:

The earth is the mother, and I the son of the earth! AV (12:12) (Bloomfield, p. 200)

Upon the firm, broad earth, the all-Begetting mother of the plants, that is supported by (divine) law, upon her, propitious and kind, may we ever pass our lives! AV (12:17) (Bloomfield, 201)

Another passage reflects a deep concern for the wellbeing of the Earth, in a sacred text composed nearly four millennia before our planetary ecological catastrophe. The verse expresses a sense of responsibility for her care and preservation:

What, O earth, I dig out of thee, quickly shall that grow again: may I not, O pure one, pierce thy vital spot, not thy heart! (12:35) (Bloomfield, 203)

This sentiment is echoed again in the following passage, which expresses recognition of the value of the rich wilderness by which the Vedic people were surrounded, as well as an assurance of protection from harm due to human settlement:

Thy snowy mountain heights, and thy forests, $\mathrm{O}$ earth, shall be kind to us! The brown, the black, the red, the multi-colored, the firm earth, that is protected by Indra, I have settled upon, [but] not suppressed, not slain, not wounded. AV (12:11) (Bloomfield, p. 200)

The hymn is an interesting testament to the clear awareness of the absolute dependence of humanity upon the Earth for all needs; everything that humans require and continue to use is mentioned. That acknowledgement, by itself, is not adequate to engender an ecological consciousness, but it is a critical step; this is evidenced by our current calamitous relationship with the ecosphere at a time in which the global commercial culture does not recognize this integral dependence at all. There is an urgency for this recognition to emerge again in our current culture. Without such awareness, we will continue to live under the illusion that the plunder and ravaging of the Earth will not impact human lives, at least not the privileged ones.

Immersed as the Vedic people were in the tropical biodiversity of vast forests, trees are also particularly understood to be animated by the power of divine presence. Tree ceremonies are still performed by Hindus today. Large trees are referred to as the "Lords of the Forests" in the Rigveda. As Indologist Hermann Oldenberg explained, plants and 
foliage materials used for medicinal or ritual purposes were offered prayers and referred to as "goddesses born of the goddess Earth ... . Plants, by this name I speak to you the Mothers, to you, the Goddesses." (Oldenberg 1988, p. 128) When a tree was cut down, concern for the injury inflicted was sacramentally expressed; a blade of grass was placed and sacrificial clarified butter was poured on the remaining tree-stump with the following prayer: "Lord of the Forest, grow forth with a hundred branches; may (you) grow with a thousand branches." (Oldenberg 1988, p. 129)

Just as the individual tree is envisioned as the "Lord of the Forest" and thought to contain a sentient self, the forest itself is viewed as the sylvan form of the devī Aranyāni ("Goddess of the Forest") who is addressed in various hymns of the Rigveda, particularly the Aranyānī Süktam (RV 10:146):

Goddess of wild and forest who seemest to vanish from the sight...

What time the grasshopper replies and swells the shrill cicala's voice,

Seeming to sound with tinkling bells, the Lady of the Wood exults.

And, yonder, cattle seem to graze, what seems a dwelling-place appears:

Or else at eve the Lady of the Forest seems to free the wains ...

Man eats of savoury fruit and then takes, even as he wills, his rest.

Now have I praised the Forest Queen, sweet-scented, redolent of balm,

The Mother of all sylvan things, who tills not but hath stores of food.

(HYMN CXLVI 1897)

The awareness of trees as living, dynamic, sentient beings related to humans is well expressed in verses spoken by the great sage Yàjñavalkya-from the highly significant Bṛhadāranyaka Upanișad (3.9.28), circa 900 BCE-that analogize the physiology of a great tree to that of the human being in the form of questions which lead to his statement on the doctrine of rebirth (Madhavananda 1950, Brhadäranyaka Upanișad 3.9.28). The Upanișadic principle of the identity of ätman (the Self) and Brahman is implicated in the passage which views the tree analogically, in a way that is only appropriate in a religious culture that experiences deep interconnection with plant life. Chāndogya Upanișad goes further still, and describes a tree as having such a self, as a sentient being, infused with consciousness, capable of pain and joy:

O Somya, if someone strikes at the root of a big tree, it will continue to live, though it may exude some [sap]. If he strikes at the middle, it will still live, though it may exude some [sap]. If he strikes at the top of the tree, it will survive .... Pervaded by the living self (ätman), the tree will keep drinking [water] and living happily. But ... if the self withdraws from the whole tree, then the whole tree will die. (ChU 6.11.1-2)

O Somya, now this: When the self leaves the body, the body surely dies. The self, however, never dies. That which is the subtlest of all is the Self of all this. It is the Truth. It is the Self. That thou art ... (ChU 6.11.3) (Lokeswarananda, italics mine)

The Upanișad is suggesting that a tree is a sentient being, like a human being with a life and a self (ätman). Just as a human being's self permeates the entirety of the body, just so the subtle self, that permeates all pervades the entire body of the tree. It is alive because it is imbued with the embodied a tmman, in opposition to a materialist thesis that the self is an epiphenomenon of the sentient being.

The concern for, and blessing of, the entire ecosphere-not only humans, and not only one's own tribe or community-is beautifully expressed in this hymn (one of the śânt $\bar{l}$, or "peace" mantras) from the Vedas:

Om.

May peace sweep through the skies and universally across the immense spaces 
May there be Peace on earth, Peace in the waters, Peace in all herbal plants, Peace and flourishing in the trees and forests

May the divine realms be inundated with tranquility

In all that exists, everywhere, may there be peace

May all be calm and ever-serene

Om peace, peace and peace to ... all beings!

(Rita D. Sherma, Yajur Veda 36:17)

The hymns of the Vedas reflect a people who saw the world as a whole and the cosmos itself, not as a secondary, illusory, or fallen realm but one of great value, significance, and wonder. When they are addressed to the devata ("lustrous divine beings"), the verses of the Vedas are invoking forces that largely represent aspects and phenomena of the natural world, or of life itself. In general, there is no authoritative figure or being that is regarded as the sole master of the cosmic order, except for the concept of Indra (the sovereign of the devatā). However, the disappearance of Indra over time, and the continued importance of those devata associated with natural forms, forces, and phenomena (such as the rivers Ganga, Sarasvatī, and the sweeping winds associated with Rudra) who transform into major devas and devis points to the significance of devatā that were associated with natural phenomena.

The hymns of the Vedas carry the concerns, aspirations, and prayers of a particular people in the context of an indigenous religion of place. But the care, concern, and devotional reverence transcend time and place. And, it has relevance for Hindus of South Asian origin today. Further, it has value for the Hindu diaspora and also for those who are Hindu practitioners, but not of South Asian origin. These verses need to come alive again and act as a counterweight to the modern loss of connection to wilderness and forests. This communion with the earth, waters, forests, and mountains of a place renders the space sacred, and gives humans time to pause and reflect in both gratitude and remorse when they take resources from the abundance of the wilderness.

For the Hindu ethos, before the time of stone temples and the trampling of the soil by the feet of an endless stream of pilgrims, before religion became a thing of material and visual culture, was a time of reverence for the natural forms and phenomena of the uncultivated world, which itself was seen as the source of life and revelation. Such as approach can be applied by Hindus globally, wherever they may be located and whatever their ethnicity. This is one of the markers of indigeneity which gives rise to a religion of place. Studies show that this shared connection and awareness of interrelationship and interdependence with a place and its ecosystem, which indigenous societies share across cultures, is beneficial for conservation and regeneration. A 2017 article in the Journal of Ethnobiology and Ethnomedicine explains this position: "Efficient conservation can be possible only when the technical expertise is combined with an understanding and consideration of the cultural practices of local communities ... . Ritual beliefs of the indigenous people are one of a prominent tools to understand the local communities and aid ... nature conservation ... . [It] can provide valuable information and link to the conservation of biodiversity." (Geng et al. 2017, emphasis mine) The article, like many similar studies, goes on to say that: "Our study shows the live ritual activities and the beliefs of the residents are keeping the plant diversity and the entire forest preserved as sacred mountains. Our study emphasizes traditional beliefs and an alternative view of conservation that is not led mainly by governmental policies, as local practices and ritual plant uses play as constant reminders ... on nature conservation." (Geng et al. 2017).

\section{Divine Immanence: Hinduism as a "Global Religion"}

In the section above, we looked at the valence of indigeneity for the emergence of eco-consciousness in Hindu experience. In this section, I seek to present the other side of the coin; that is, the global or universal eco-vision that is also present in Hindu thought from the time and texts of the Vedas. I have developed the term "radical immanence" (the title 
of my forthcoming volume) in relation to Hindu theologies of deep immanence wherein the Divine transforms into physical reality. The term is oppositional to what I refer to as theologies of "exclusive transcendence" in any religion that holds that the Divine lies outside of and beyond physical reality. These are the doctrines-across religions-that seek to exclude and transcend the value of the ecosphere, embodiment, and eros (by which I mean an integrative embrace of life, a refined ecologically attuned aesthetic that is situated in sensorial biophilia). However, immanence can be variously conceived; not all such conceptions are helpful for fostering eco-consciousness and action. What is useful is a conception of deep immanence which posits that the Divine is present in physical reality, in matter itself. In Hindu theology, this is the prime characteristic of theologies that offer primacy to Śakti, the Divine Feminine in Hinduism.

The notion of "radical immanence," while most vividly and explicitly present in the theology of Śakti, has a long history in Hindu thought. The first glimmer of this vision is found in two well-known hymns from the Rgveda samhitā (1900-1700 BCE): the Purusa Sūktam (RV 10:90) and the Devī Sūktam, also called the (Aṃbhṛnī Sūktam), (RV 10:125).

\subsection{The Devī Sūktam}

As I have noted elsewhere (Sherma 2019), the specific understanding of the Divine Feminine as the Ultimate Reality that is immanent in every dimension of experience is first expressed in a hymn from the Rigveda, known as the Devī Sūktam ("Praise to the Divine Feminine," RV 10.125). Composed by an eminent woman sage (rșikā) known as Ambhrani, it is written as an exclamation of her self-experience as the all-in-all, as the Devī, arranged in the style of remembrance of an ecstatic, singular revelation of the supreme Self as deep immanence-boundary-less and all-pervasive. Verses from the hymn, the Devī Sūktam, bear witness to her experience as the Divine Feminine:

I am the Queen, the gatherer of treasures, established in/as Ultimate Reality, the Primary Object of Worship.

The Luminous Divine Powers (devāh) have dispersed me in many places, having many abodes, causing me to be All-Pervasive.

(Verse 3)

Even eating, seeing, breathing, or hearing the spoken word is accomplished through me alone. Even the non-perceivers amongst you dwell near me. Hear me, for I reveal the truth.

(Verse 4)

While creating all beings, I merely breathe forth like the wind. So expansive is my power, possessing a greatness beyond heaven and earth.

(Verse 8)

The Devī Sūktam put forth a vision of the Divine Feminine as an organically immanental, experienceable, creative power and presence within matter and embodiment itself-an early harbinger of the powerful immanental theology of the Divine Feminine which would later explode onto the Hindu theological scene in texts such as the circa 5th century Devi Mahātmyam (Glorification of the Supreme Goddess).

\subsection{The Puruṣa Sūktam}

This is a remarkable text which envisions the Supreme Being (Purusa) transforming

Himself into each and every creature of the world and, indeed, the entire cosmos. Individual creatures are named as they issue forth from parts of His primordial form as He sacrifices Himself into a cosmic fire from which emerges the forms and beings of the universe. From within the cosmic sacrificial fire the cosmos arises created from the essence of the Purusa. Here, again, the Divine transforms into the cosmos and the life of living beings. 
Yet, the hymn is also explicit about His transcendence. He remains both organically immanent in the universe and yet possesses the divine freedom of transcendence. This organicity that marks the deep, immanental relationship between the Supreme Being and the world, affirming the uniqueness of species and the diversity of beings, is known as bhedabheda (difference and non-difference, or simultaneous oneness and multiplicity). This viewpoint has had a significant impact on Hindu theologies, particularly certain Vaiṣnava theologies. David Haberman explains this from the viewpoint of Kṛnna bhakti:

Many scholars agree that the Purusha Sukta of the Rig Veda, which gives expression to the simultaneity of radical unity and diversity (bhedabheda), has played a significant role in the development of Bhagavata theology. There is, therefore, no better place to begin an introductory understanding of Bhagavata theology than with the Purusha Sukta of the Rig Veda. (Haberman 2006, p. 34)

In the vast, fiery, cosmic kenosis that produces the world through the self-emptying sacrifice of the Supreme Being, one-third of Purusa transforms into the ever-changing realm of physical reality and two-thirds remain transcendent. Several important doctrines that later inform various Hindu theologies are implicit here. There are four Hindu doctrinal ecologically significant implications of the Puruṣa Sūktam:

1. The Divine can be understood as "radically immanent" in the cosmos through selftransformation alone.

2. All beings are equal in value as they are all created from the essence of the Supreme Divinity.

- There cannot be discrimination, classism, racism, gender bias, bigotry, anthropocentrism, speciesism, or even "sentientism," because all things and beings in the cosmos are equal transformations of the Divine Body.

- Whenever the Purusa Sūktam has been or is used to justify any of these joint oppressions, what occurs is a complete inversion and perversion of the embracing nature of the doctrine of radical divine immanence as the heartbeat and rhythm of the world.

3. This organic radical immanence does not exhaust the Divine, and the concept of divine infinitude is well expressed in the oft-recited pürnam śānti mantra:

pürnam adah, pūrnam idam, pūrnāt pūrnam udacyate

pūrnasya pürnam àdāya pürnam evāouasis yate.

That (Divinity) is infinite; this (creation) is infinite

Infinitude flows from infinity

Taking the infinite from infinitude, infinitude yet remains. (Rita D. Sherma, Bṛhadāranyaka Upanișad, verse 5.1.1)

The mantra expresses the nature of the Divine as infinitude/wholeness; that which requires nothing in its perfection and completeness. Therefore, even as the infinite multiplicity of the temporal cosmos proceeds from the eternal Divine (immanence), the infinitude of the Divine still remains (transcendence). This understanding of the interrelationship of transcendence and immanence is also well-expressed in the Purusa Süktam which is, therefore, a major foundation for understanding the relationship between divine transcendence and immanence.

4. Also implied here is the doctrine of satkāryavāda—developed later in Sāmkhya, one of the six systems of Hindu philosophy-and it continues to inform the relationship of the Divine to creation in a variety of Hindu theologies. This doctrine of causation holds that the cause is present in its effect, even if only in potential form.

5. The doctrine of parināmavāda is also indicated in the Purușa Süktam. This is the doctrine of transformation which holds that the cause transforms itself, in an ongoing process, into its effects without being changed by these processive transformations.

All five doctrinal implications of the Purușa Süktam are highly significant to the doctrine of "radical divine immanence" which, as I argue in my forthcoming work, marks Śakta theology as especially conducive for an ecological vision. 


\subsection{Sentient Beings: Others on the Path of Life}

There is the presence of anthropocentrism due to the (perceived) unique human ability to recognize the immanental Divine, evidenced by the high valuation of what is known as "precious human birth" in both Hindu and Buddhist ancient texts. This view, however, is balanced by many Hindu texts that reflect a lack of a hierarchical dualistic distinctions between humans and others on the journey of life. This sense of connection to others on the chain of being is amply attested to by the close relation of deities whose lives and actions are connected with the world of various animals, as narrated in the Purāna (narrative theology texts) and Itihāsa (the two great epics). Prime examples include Rāma's ubiquitous helper and disciple Hanumān (the wise, courageous, and generous monkey who is remains deeply venerated as the embodiment of bhakti, or loving devotion to God), and the association of Kṛ̣na with his beloved cows in the pastoral Vṛndāvana, as well as the animal avatāras of Viṣnu (Edelmann 2012) ${ }^{1}$.

This is further strengthened by the existence of zoomorphic deities such the ubiquitous Ganesh, or the devī Vindhyavāsinī, a form of the supreme Divine Feminine. The Vaisnava principle of avatāras is, arguably, the most lucid illustration of Hindu integration of otherthan-human life into the realm of the sacred to be found in systematic theology. The doctrine proposes the ten divine incarnations (or more, depending on the source) that include Rāma and Kṛ̣ṇa, but also include non-human species such as a fish, a tortoise, a boar, and a man-lion (Narasimha). Thus, other forms of life are seen as part of a holarchical rather than hierarchical chain of consciousness. It follows, therefore, that animal and plant life are always worthy of our empathy and, at times, of our reverence as embodiments of the Divine.

The global pandemic of 2020 shares a common link to the climate catastrophe and mass extinctions: the malrelationship of human civilization to the biosphere. Whether it is trade in wild animals causing the transference of zoonotic diseases, the lack of urgency in transitioning to renewable energy, or the utter absence of care and compassion for species disappearing forever, a civilization living without telos will render life on earth untenable. Alternatively, we will transform societies, economies, and cultures in order to live in congruity with visions of a higher purpose, and find the way back to an integral interrelationship with the biosphere. There is no third option. Religions are important wellsprings of resources for such a transformation.

Funding: This research received no external funding.

Conflicts of Interest: The authors declare no conflict of interest.

\section{Notes}

Edelmann (2012) explains the strong theological significance of this in his book Hindu Theology and Biology: The Bhagavata Purana and Contemporary Theory.

\section{References}

Edelmann, Jonathan B. 2012. Hindu Theology and Biology: The Bhagavata Purana and Contemporary Theory. London: Oxford.

Geng, Yanfei, Guoxiong Hu, Sailesh Ranjitkar, Yinxian Shi, Yu Zhang, and Yuhua Wang. 2017. The implications of ritual practices and ritual plant uses on nature conservation: A case study among the Naxi in Yunnan Province, Southwest China. Journal of Ethnobiology and Ethnomedicine 13: 58. Available online: https:/ / doi.org/10.1186/s13002-017-0186-3 (accessed on 15 June 2020). [CrossRef] [PubMed]

Haberman, David. 2006. River of Love in an Age of Pollution: The Yamuna River of Northern India. Berkeley: University of California Press. HYMN CXLVI. 1897. Aranyani. In Rig Veda. Translated by Ralph T.H. Griffith. Benares: E. J. Lazarus \& Co, vol. II, Available online: https:/ / www.sacred-texts.com/hin/rigveda/rv10146.htm (accessed on 22 June 2021).

Swami Lokeswarananda, trans. Chandogya Upanisad: Translated with Notes based on Shankara's Commentary, Kolkata. Kolkata: Ramakrishna Mission Institute of Culture.

Swami Madhavananda, trans. 1950, Brihadaranyaka Upanishad_Shankara Bhashya. Mayavati: Advaita Ashrama.

Oldenberg, Hermann. 1988. Religion of the Veda: Die Religion Des Veda. New Delhi: Motilal Banarsidass Publ.

Sherma, Rita D. 2019. God the Mother and Her Sacred Text: A Hindu Vision of Divine Immanence. In The Bloomsbury Research Handbook of Indian Philosophy and Gender. Edited by Veena R. Howard. New York and London: Bloomsbury Academic. 